https://jurnal.unigal.ac.id/index.php/jall/index

JALL (Journal of Applied Linguistics and Literacy), ISSN 2598-8530, September, Vol. 4 No. 2, 2020

\begin{tabular}{|ccc|}
\hline Received & Accepted & Published \\
\hline August 2020 & September 2020 & September 2020 \\
\hline
\end{tabular}

\title{
THE ANALYSIS OF STUDENTS' ABILITY IN WRITING SHORT STORIES
}

\author{
Ikin Syamsudin Adeani \\ ikinsyamsudin@gmail.com \\ Indonesian Education Department, Universitas Galuh
}

\begin{abstract}
This researchis aimed to determine the students' ability of Indonesian Education Study Program,Faculty of Teacher Training and Education, Galuh Ciamis University, in writing short stories. The students are still lack of studying the literary of short story, instead they tend to read the popular short stories. The method used in this research is descriptive method. The results of this study are as follows. First, to obtain the clear illustrationwhether the students are able to write literature short stories or popular short stories. Second, to position their short stories in the development of Indonesian short stories, especially among students.
\end{abstract}

Keywords: analysis, writing short story, literary short stories, popular short stories

\section{INTRODUCTION}

Language skills include four aspects. First, the aspect of listening skill, second, aspects of speaking skill, third, reading skill, and the fourth is writing skills. The four language skills are related to each other. The four language skills not only support within the scope of the language but also in the scope of life (Septiaji, 2017). Ideally, all these skills must be mastered by every student. Of the four language skills, there is the difficult skill, namely writing skills, more specifically is short story writing skills as it is also mention in Halim, Hartati, \& Lestari (2019).

Short story writing skills include two elements, namely intrinsic elements and extrinsic elements. Intrinsic elements are elements that build literary works from inner-self (Sastrawacana, 2018). The intrinsic elements consist of themes, time and place settings, atmosphere, plot, characterization, point of view, moral values, and 
message. Themes are the main concept, ideas, or main thought that become the basis of story. Characterizations are imaginary individuals who experience events in a story. Plot is the series of events in a literature work to achieve certain effects. Setting is all information about place, time and atmosphere. Characterization is the techniques of the author of how to perform the character of the character in the story. Viewpoint is the way of the author of how to perform stories. The speech is the message that the author wants to convey to the reader (Qipper Blog, 2018). In addition, extrinsic elements are elements that build literary work derive from the outside of the author (Sastrawacana, 2018). Extrinsic elements are as follows 1) the background of a creation refersto when the literary work is created; 2) social condition refers tothe social condition either in the economic, social, cultural, or politic, at the time the literary works are created. In other words, the factors such as the biography of the author, religion, and the philosophy adopted by the author, history, socio-economic conditions of the community that underlie the creation of literary works (Quipper Blog, 2018).

In the study of literature, we know two kinds of literatures. First, serious literature (interpretative literature). This kind of literature needs the readers to interpret its work. Second, entertainmentliterary or escape litetature (Admin, 2018). Serious literature work demands the reader to interpret the literarywork in a deep contemplation, while entertainment literature works is to escape boredomfrom the daily routinethat is difficult to resolve. Becauseof that, suchliteratury works are called also popular literature orpopliterature.

The differences between popular and serious literaturesare as follows: 1) popular literature is not too intense in revealing the essence of life while serious literature much emphasizes the nature of life in depth; 2) the content of popular literature tends to be mild, so that its content is easier to read, while serious literature is more weight, so it requires a higher concentration of reading power; 3) popular literature tends to be more devoted to the taste of its reader, while serious literature does not have many readers; 4) popular satra provides entertainment directly from its content, while serious literature pursuits of aesthetic effects; 5) popular literature is more stereotype and does not prioritize elements of renewal, 
while serious literature is not so stereotype that there are many renewal elements (Rokhmansyah, 2011).

In the Indonesian Language Curriculum of Faculty of Teacher Training and Education,Galuh University, it has been explained that Writing Skill is taught in the fifth semester in two credits. One of these skills is learn to write short story. Theoretically and practically, literary writing learning has been taught to the students. In practice, the main problem of this research is to know how students are able to write short stories. Is the literary work written by the students classified into popular short story or short story? Among the students, to which level is the short story written by the students of Indonesian Education Study Programof FKIP Galuh University included? This research is conducted to find out the absorption of students in the ability to write short storyand its implication in developing short story writing skill in daily life.

\section{METHOD}

This research is a qualitative research using descriptive method. This descriptive research produces the descriptive data in the form of short stories written by the students. This method is accomplished by using deep understanding and empirically studied. The possibility of the short stories studied is classified into two groups. First, popular short stories group, second, literary short stories group. Popular short stories only stimulate the reader to read but not to interpret (Darma, 2019: 6). Second, the literary short stories group (short stories that require deep thought). As Darma reveals that serious literature offers deep reflection or contemplation (Darma, 2019: 7).

\section{RESEARCH RESULTAND DICUSSION}

\section{RESEARCH RESULT}

Synopsis of the first short story entitled Cinta dalam Rindu by As.

I admired Taufik, missed him until carried away in a dream. In the next meeting, I was invited to his birthday party. This time I was wearing a hijab so that I was hardly known. 
At his birthday party, Taufik brought a song for the girl next to me. It made me feel uneasy and wanted to go home. That girl then hugged him. The love that had beenkeptsince a long time got dispersed.

Before going home, Taufik held my hand while expressing his love. All friends supported him, and so did that girl. Taufik's love was only to me, that girl was just his best friend. My heart turned to be so cheerful because of his love.

\section{Intrinsic Elements:}

1. Theme: don't be hopeless so fast

2. Setting: Daytime

Proof: I really wanted to go home fast

Place: In a cafe

Proof: "Taufik! The girl screamed calling him.

3. Situation: sad and cheerful ending

4. Plot: forwarding

Proof: the plot is explained starting from the introduction to the conflict solution

5. Characterization:

I : quiet girl with deep love.

Taufik: kind young man with many friends

Shila: Taufik's best friend

Friends: support Taufik's love

6. Viewpoint:

The first character is the main character. This short story used personal pronoun "aku" as the main character and tell about herself.

7. Value

Moral Value: keep quiet by watching better than acting up a lot of behavior

8. Message: Don't easily give up in thislife and be sure to the destiny of Allah.

\section{Extrinsic Element}

Extrinsic element contained in this short story is the moral value, namely the level of patience on the part of women is very necessary to achieve essential happiness. 
Synopsis of second short story entitledTasbih Cinta Shafaby El.

Shafa had long been enough to have relationship with Dava. His sincerity hadconvinced Shava's heart to wait for his proposal. Unfortunately, the relationship between the two of them was not blessed by Shafa's parents because of their different religions. Anyway, Dava had to think about their relationship again. Since then Dava just disappeared. Only to Pipit was one friend to pour out his heart.

One night, Shava received Pipit. With great doubt, Pipit handed over an envelope containing photos from her old friend. Upon returning from Pipit, the envelope was opened, to Shafa's surprise, it turned out that the photos were Dava's wedding photos with the girl of his choice. Seeing that reality, Shafa cried. His heart received God's fate that Dava was not his soul mate.

Intrinsic Elements:

1. Theme:mate is in the hand of God.

2. Setting:

Place: night time

Proof: she welcomed Pipit entered her house soon

Time: In seconds, a happy wedding photoswereattached

3. Situation: being sad as failed to get married

4. Plot: Forwarding

The plot was begun from the introduction to the conflicts and ended with the solution of the story

5. Characterization:

Shafa: failed to have a love because of the different religion

Dava: a young man who is firmed with religion

Pipit: a girl who became Shafa's best friend

6. View point:

The third character became the main character. This short story used the third character (Shafa) to be the main character and revealed her relationship with her lover who was different religion

7. Value:

Moral Value: being patient to receive the fate of God

8. Message: being patient while praying to have a couple blessed by Allah. 


\section{Extrinsic Elements}

Extrinsic elements contained in this short story are moral values, the need for a high level of patience accompanied by a prayer to God.

Synopsis of third short story entitledAku, Kamu, and Dia by Ev.

Lia started to know Rizal by telephone. Their relationship was getting closer and finally fell in love. One day Rizal did not want to pick up Lia. Once time, seeing Rizal riding on Sulis. They looked very affectionate. Inquired of having been curious, it turned out that Sulis was indeed dating with Rizal. When asked about the problem, it was admitted that Rizal was dating with Sulis. Hearing his confession, Lia felt cheated by Rizal and she did not want to get close to such a man like him.

Intrinsic Elements:

1. Theme: love cheater

2. Setting:

Place: Day time

Time: Week after week had been passed by Lia, but she was very curious about the relationship between Sulis and Rizal.....

3. Condition: Much disappointment

4. Plot: Forwarding

The story line was arranged neatly starting from the introduction to the conflicts which then went down to the solution.

5. Characterization:

Lia: the innocent girl who loved Rizal

Sulis: Lia's best friend who grabbed Lia's boyfriend

Rizal: a young man who liked making a pool of a woman

6. View point: 
The third characterbecame the main character. This short story used a third charcter (Lia) to be the main character and told about herself and her boyfriend who liked cheating

7. Value:

Moral value: being patient because her boyfriend was cheating

8. Message:by being patient while praying to Allah. God willing, it would be reunited with his soul mate

\section{Extrinsic Element:}

Extrinsic element contained in this short story isa moral value, the need for a high level of patience accompanied by a prayer to God until the future time that she would be met with her soul mate.

Synopsis of the fourth short story entitled Di Antara Dua Hati by Ik.

Aini had been in contact with Dulfi for two years. However, in the past three months he had been in love with Fazri. He was an adult man who knew Aini's heart. He was more open to Aini's family. One day Fazri was sick. Aini intended to visit and bring his favorite food. When reaching his boarding room, how surprised Aini's heart saw Fazri kissing with his male friend, Bisma. From that moment Aini no longer had anything to do with the immoral man. Aini regretted the decision she had made.

\section{Intrinsic Elements:}

1. Theme: love cheater

2. Setting:

Place: cried on the way home

Time:I wished he would be happy and healed when being visited by me

3. Situation: full of disappointment.

4. Plot: Forwarding

The storyline was arranged neatly starting the introduction to the conflict continued to the solution

5. Characterization:

I: a woman who made a mistake to choose a man

Dzulfi: the man whose love was left behind 
Fazri: a lesbian guy

Bima: a lesbian guy

6. View point:

The first person became the main character. This short story used the first person to be the main character and told about herself and her lesbian boyfriend

7. Value

Moral value: being patient and soon left him because her boyfriend was a lesbian or gay.

8. Message: being patient while praying to Allah. God willing, it would be reunited with his soul mate

\section{Extrinsic Element}

Extrinsic element contained in this short story wasa moral value, the need for a high level of patience accompanied by a prayer to God so that one day she would be met with her soul mate.

Synopsis of the fifth short story entitled WAITING FOR THE DUSK by Lin.

Waiting for someone who was missed for so long was tiring. The heart idol had not returned for a long time. I still loved you like dusk picking up the night peacefully. Finally, he lost his faith to the point that he wondered if she missed him. The only memorable song "Hanya Rindu" became a friend at that time.

\section{Intrinsic Elements:}

1. Theme: waiting someone who did not comeback

2. Setting:

Place: in the dusk.

Time: ... and I was still waiting until this time

3. Situation: painful

4. Plot: Forwarding

The storyline was arranged neatly starting the introduction to the conflict continued to the solution

5. Characterization: 
I: a lonely girl because of being left behind by her soul mate

He: a young man who went away with no news

6. View point:

The first person became the main character. This short story used the first person to be the main character and told about her loneliness

7. Value:

Moral value: being patient and hopeful

8. Message: waiting for a long time made her more patient

\section{Extrinsic Element:}

Extrinsic element contained in this short story wasa moral value, the need for a high level of patience accompanied by a prayer to God so that one day she would be met with her soul mate.

Synopsis of the sixth short story entitled JERA by Ci.

I knew Andre through Shasa by telephone. Recently, he often called me about cats and the same type of music. They were rarely together because bothof them had a busy life. My relationship with him almost broke up because he closed himself. The love that started to grow was going to be left.

Lala was my loyal friend. From her,I knew that liked to play girls. Seeing that reality, I don't want to relate to him anymore. I let him belong to another woman. One day he (Andre) came back to me and tried to seduce me again. I stuck my position, I didn't want to see his face again. Goodbye.

\section{Intrinsic Elements:}

1. Theme: don't want to be a male game

2. Setting:

Place: Day time

Time: it is going to be the nigh time, but there is no really dusk as usual

3. Situation: heartache should not be dragged on, there must be a limit

4. Plot: forwarding

The storyline was arranged neatly starting the introduction to the conflict continued to the solution. 


\section{Characterization:}

I : a patientgirl who is, and is steadfast in her stance

Andre: young man who likes play love

Lala: a loyal friend of "I" character

6. View point:

The first person becomes the main character. This short story uses the first person to be the main character and tells about his heartache because of young man

7. Value:

Moral value : be patient and steadfast in your stand

8. Message : high patience and keep praying to Allah the Almighty his soul mate will be facilitated

\section{Extrinsic Elements}

Extrinsic elements contained in this short story are moral values, the need for a high level of patience accompanied by a prayer to God so that one day they will meet their faithful partners.

Synopsis of the seventh short story entitledLOVE NEVER COMES by Ni.

The meeting on the bus after school was very thrilling. Misya was a gentle and beautiful girl. As a better way to get closer, he borrowed a book and he agreed to his loan. His feeling was in the air so high, and then he wrote a love letter later.

On a SchoolFarewell Day, abeautiful dream with Misya was foundered. He has found everything more than me. I was forced to stop loving him because he had found an established young man.

\section{Intrinsic Elements:}

1. Theme: lost hope

2. Setting:

Place: Daytime

Time: About 25 minutes the bus arrives at Misya's destination...

3. Situation: loosing hope makes the heart sad

4. Plot: forwarding 
5. The storyline is arranged from the introduction to the conflict continues to the resolution of the conflict (love never comes)

6. Characterization:

I : young man who does not get his love

Misya: beautiful girl whom Rehan loved

Young man: Misya's boyfriend

7. View point:

The first person becomes the main character. This short story uses the first person to be the main characterand tells the story of himselfbeing hurt because the established young man has taken Misya

8. Value:

Moral Value: be patient and still have another replacement

9. Message: reach the idea first then to achieve love

\section{Extrinsic Elements}

Extrinsic elements contained in this short story are moral values, the need for a high level of patience accompanied by a prayer to God so that one day they will meet their faithful partners.

Synopsis of the eighth short story entitledMAWAR BERDURI by Ai.

Ifan was thinking about Dinda. In his heart, Dinda's love was the only was expected. One day they went together at the high school reunion. That moment was the right time to express his heart to Dinda. Arriving at that place, Dinda wanted to go to the toilet. On the way, accidentally Dinda met Dea. Having finished from the toilet, they sat in the back of the garden. Dea conveyed Dinda's longing. They cuddle like lovers. Ifan who was peeking from behind really felt disappointed. It was found that Dinda was really a lesbian. Being disappointed, Ifan left them both.

\section{Intrinsic Elements:}

1. Theme: disappointment

2. Setting:

Place: high school reunion day

Time: Day time 
3. Situation: lost of hope as his lover was alesbian.

The storyline is arranged from the introduction to the conflict continues to the resolution of the conflict (his lover is a lesbian)

4. Plot: Forwarding

The storyline is prepared starting with the introduction to the conflict continues to the conflict resolution (forced to part because of disappointment)

5. Characterization:

Ifan: a normal youngman

Dinda: a lesbian girl

Dea: a lesbian girl

6. View point:

The storyline is prepared starting with the introduction to the conflict continues to the conflict resolution (forced to part because of disappointment)

7. Value:

Moral Value: be patient because as his lover is a lesbian

8. Message: find a girl who has normal behavior

\section{Extrinsic Elements}

Extrinsic elements contained in this short story are moral values, high patience must be possessed by a man to get a normal partner. Lesbian is a behavior that is not normal in God's view.

\section{DISCUSSION}

Language proficiency is very important in writing short stories. It is reasonable that there should no be mistakes in language aspect in writing short stories. Such EYD (Indonesia Completed Spelling) mistakes can be seen from the short stories written by the students, as follows:

First, shortstory of Cinta dalam Rindu.
Mistakes
Should be
memimpikanya, kemauanya
memimpikannya, kemaunnya
Aku tau
Aku tahu
Masing masing
masing-masing 
The first error is the word plus the suffix -nya, so the letter $\mathrm{n}$ is written twice. The second mistake is influencedby Sundanese language, it should be written "tahu". Next,the third error without the joining sign (-) should be written respectively.

Second, short story ofTasbih Cinta Shafa.

Mistakes

Should be

3 bulan

tiga bulan

meletakan

meletakkan

isya

Isya

The first error in figure 3 must be replaced with letter "tiga". The second mistake is the location of the word plus the suffix "-kan" the letter "k" should be two letters. The next statement is that the word "isya"should be written in the capital"Isya" because of religious affairs.

Third, short story of MAWAR BERDURI.

Mistakes

Should be

di barengi

dibarengi

diseberang

di seberang

ifan

Ifan

ku rindu

kurindu

The first error is that prefix "di-" must be coupled with the word following it to be written together. The second error is preposition should be written separately with the word following the word "di seberang". The third mistake is the name of a person written in lowercase letters, it should be capital letters like Ifan. The fourth error in writing personal pronoun "ku-", it should be written in a word following to it, it should be written "kurindu".

Fourth, short story of KASIH TAK SAMPAI.

Mistakes

rehan

di sadari

menggaruk-garukan

tau

ranting nya
Should be

Rehan

disadari

menggaruk-garukkan

tahu

rantingnya 
The first mistake of the first letter of a person's name should be written in capital letters, so it should be "Rehan". The second mistake is writing the prefix of "di-" is not in series, it should be written in a series with the word that follows to it "disadari". The third mistake is the suffix "-kan", if it is added with the word "angguk" so the letter"k" becomes double as "menggaruk-garukkan." The fourth mistake is the word "tau" due to the influence of Sundanese, it should be written "tahu". The fifth mistake is writing the suffix "-nya" which is not written in a series with the preceeding word, it should be written "rantingnya".

Fifth, short story ofJERA.

Mistakes

Darisanalah

terus terus

ku tuliskan

dibalik
Should be

$$
\text { Dari sanalah }
$$

terus-terus

kutuliskan

di balik

The first mistake is that the two words written in a series, it should be written separately, so it should be "dari sanalah." The second mistake is no hyphen in the repeated word, it should use hyphenmark and thus written as "terus-meneus." The third mistake is in the prefix "ku-" is not written in a series, it should be "kutuliskan." The next mistake is that preposition is equated with the prefix "di-“, the preposition should be written separately, so it is written "di balik."

Sixth, short storyMENUNGGU SENJA.

Mistakes

tunggu menunggu

disini

doa - doa ku
Should be tunggu-menunggu

di sini doa-doaku

The first mistake is writing the repeated word that does not use the joining sign (-), it should be written "tunggu-menunggu". The mistake of writing prepositions coupled with the words following it, it should be written separately, so it is written "di sini." The next mistake is writing the separated repeatedword and uncoupled suffix "ku", so it should be written as a series of "doa-doaku". 
Seventh, shortstory Di antara Dua Hati.

Mistakes

diatas

hari hariku

kekanak kanakan
Should be

di atas

hari-hariku

kekanak-kanakan

The first error is in writing preposition in which it is written in a series with the word following to it, it should be written separately namely "di atas." The second error is writingthe repeated word that does not use hyphen mark (-), so it should be written "hari-hariku." The next mstake in writing the repeated word that does not use hyphen mark (-), so it should be written "kekanak-kanakan."

Eight, short story Aku Kamu dan Dia.

$\begin{array}{ll}\text { Mistakes } & \text { Should be } \\ \text { lia } & \text { Lia } \\ 2 \text { minggu } & \text { dua minggu } \\ \text { lama kelamaan } & \text { lama-kelamaan }\end{array}$

The first mistake is in writing the name of a person in lowercase letters, it should be written in capital letters, so it should be written "Lia." The next mistake is writing the figure 2, it should be in letter (dua) so it should be written "dua minggu." The last mistake in writing the repeated word that does not use hyphens (-), it should be written "lama-kelamaan."

In addition to the use of language, the more important of short story is processing the theme. The theme that is processed can be traditional and nontraditional themes depending on the ability of the author. The depth of the short story lies in the author's experience in processing theme. The following is a short story analysis in terms of the processing of the theme.

First, short story of Cinta dalam Rindu.

In this short story, it was told that two teenagers got acquainted with each other. Eventually, the woman got closer and she finally fell in love with the young man named Taufik. But, she putits feeling in her heart. On one occasion at a birthday party, Taufik had a chance to hug another girl. That action made the main character hated it but was hidden away until she wanted to leave the birthday party. 
Before returning home, Taufik intercepted her. Taufik held her hand while expressing his love. All his friends shouted in support of him, including the girl whom Taufik had embraced earlier. Apparently, they were friends. Finally, she happily accepted his love

Such a love story is common among teenagers. This short storyis a popular style. The author gave score 75 .

Second, the short story of Tasbih Cinta Shafa.

The characters in that short story seemedto be more mature because they had been dating for a long time and were waiting for marriage. Dava's maturity had convinced Shafa's heart. But Shafa's father thought that it was not only mature, but also belief was more important. Dava's religion was different with Shafa's; so their relationship was not approved by his father. Since then, Dava disappeared.

Everything was only devoted out on Pipit, Shafa's only friend. One night Pipit visited to Shafa to send the envelope. Having Pipit returning home, Shafaopened the envelope and found that there was a photograph of Dava's wedding with another girl. How disappointed Shafa's feeling was that she got crying. Finally, Shafa accepted God's destiny that he was not her soul mate.

This short story looked more complicated than the first one. Her separation was not because of love, but different religion. The author gave a value of 80 even though it was popular style.

Third, short stories KASIH TAK SAMPAI.

The initial meeting on the school bus continued to subsequent meetings. His approach to borrowing her book got successful. Then he ventured himelf to make a love letter. Day after day, his love to her was getting abundance.

Misja, on a farewell party, a tender and sincere girl was handed by a young handsome boy who was far more everything than me. Beautiful dream with Misja blew around. Beautiful flowers that began to bloom instantly withered buds no longer passionated. This short story has a popular style and the writer gave score 75.

Fourth, the short story of JERA.

This story started from the similarity of cats and the similar type of music. This closeness was getting more intimate relationship. This intimacy is increasingly 
changing because of the different activities. However, the more I love, the more I wasted. From Lala, I got the news that Andre frequently played with women. One day, he came to me with his seduction. But I refused his presence because he came just to leave me again. He's the type of guy I don't expect. Even now I'm sick of seeing it.

The short story is a kind of popular style by displaying Andre's character who likes changing girlfriends. The character of "I" is not the type of woman who likes to be played with love. Therefore, she does not want to see his face again.

This short storybelonged to the popular short story. The author's assessment of the short story was 75 .

Fifth, short story of MENUNGGU SENJA

The act of waiting for beloved friend for so long was very boring. Moreover, the beloved one whom was being waited for was no news. Until she lost her faith, in her heart, she wondered whether she still loved her or not. All that's left was the memory song "Hanya Rindu" that was floating in her heart.

For a woman who was so patiently waiting for the presence of beloved one was in vain. This short story was still in a popular style and the writer gave score 75 to it.

Sixth, the seventh short story of Diantara Dua Hati.

The love story between Aini and Dulfi could be said as mediocre. They had been in relationship for more than two years. Lately, Aini prefered to choose Fazri, because he was more mature, open to Aini and her family. So, Fazri was her last choice and Dulfi abandoned her. One day, Fazri got sick, Aini intended to visit him and brought his favorite food.

Arriving in his boarding room, Aini got disappointed when she saw Fazri kissing Bisma, his male friend. Seeing the strangeness like that, she was sure that Fazri with Bisma were both gay. She felt very sorry choosing Fazri and soon she left the two of them with deep emotional wounds.

The processing the theme of its story could be classified into a new theme. This short storywas included into non-traditional themes. The author gave score 90. Seventh, the short story of Aku,kamu dan Dia. 
The story of the short story was begun with an introduction by telephone. The longer it got, they finally got dating. One day, Rizal did not want to pick her up. Even, he was closed with Sulis. When he was asked directly about his relationship with Sulis, Rizal answered firmly that she was his girlfriend. Rizal's careless attitude made her uncomfortable. Finally, Lia felt sorry for having been fooled by the irresponsible man.

Such an action like that is often carried out by men. This short story was classified as popular short story. The author gave score 75 .

Eighth, the short story ofMawar Berduri

The love story of Ifan with Dinda was very happy. One day, they went to a high school for reunion. That was the right time to express his true love. When Dinda asked for permission to the toilet, she accidentally met Dea, her female friend. It turned out they were already closely related lovers. Both of them embraced as if they werea pair of lovers. That was finally known by Ifan. Seeing this reality, Ifan felt disappointed because Dinda and Dea were lesbians. Sorrowfully, he left those who were mad in love. The story of the lesbian lifewas a story cursed by God and as a short story it was included into the non-traditional story. The author gave score 90.

\section{CONCLUSION}

At the end of this part, writer wants to convey some conclusions. First, the ability of students to write short stories is generallystill at a basic level. In terms of form, there are still some errors, especially in the use of EYD (Official Indonesian Spelling System). For the author (the students), in the case of writing short stories, they do not make any mistakes in accordance with the terms of EYD usage. Second, in terms of content (theme), the students can develop their writing into the traditional themes based on their experiences, except for the two students who have been able to write non-raditional themes. Third, in terms of comparing the short story writing development, the students of outside Galuh University need a special training especially in the basic group. In general, the training of short story writing in terms of improving knowledge should be continued outside of the meeting hours (extracurricular). For example,improving and comprehending the philosophy, 
psychology, social, economics, history, politics and religion. Thus, the discussion of problems in the short story is not only a matter of youth love, but more in-depth to the non-traditional theme (serious satra or true satra). It was stated by Budi Darma that the difficulty to write mainly stemmed from the lack of a person's ability to think critically. Perception of obscurity is a source of weakness for someone to find problems that can be written (Darma, 2007: 4).

\section{REFERENCES}

Admin. (2018). https://ceentina.com/sastra-serius-dan-sastra-hiburan.

Darma, Budi. (2019). Pengantar Teori Sastra. Penerbit Buku Kompas.

Ejaan Bahasa Indosesia yang Disempurnakan EYD Terbaru (Permendinas Nomor 46 Tahun 2009). (2010). Yogyakarta: Pustaka Timur.

Halim, I. A., Hartati, A., \& Lestari, Z. W. (2019). THE USE OF PORTFOLIO ASSESSMENT OF WRITING SKILL IN DESCRIPTIVE TEXT. JALL (Journal of Applied Linguistics and Literature), 75-85.

Quipper Blog. (2018). https:quipper.com/id/blog/maple/bahasa-indonesia/unsur intris.

Rokhmansyah, Alfian. (2011). http://www.alfianrokhmansyah.com/2011/10/sastraserius-dan-sastra.

Sastrawcana. (2018). https://sastrawacana.id/mengenal-unsur-intrinsik-danekstrinsik-karya.

Septiaji, Aji. (2016). https://www.kompasiana.com/ajiseptiaji/5a436eOf5e1373752f7a5f23/k 